\title{
ANDOR KLAY \\ Hungarian Counterfeit Francs: A Case of Post-World War I Political Sabotage
}

Stalin's little-known 1928 caper, the production and distribution of bogus hundred-dollar bills, ${ }^{1}$ was preceded by an even less known venture of the same sort. Specialists in East European history have left it unexplored during the decades which have passed since it occurred, and several aspects of the plot behind it, as well as some of its most powerful supporters, remain unknown. It happened in 1925, and involved a string of high-ranking Hungarian civilian and military personages, with a prince at one end and a bishop at the other.

The ultimate fiasco of the bizarre Hungarian enterprise was not caused by the kind of general mismanagement which plagued the Russian action. Its collapse came as a result of weak nerves and ill luck on the part of a single individual. The principal motives were also different. The Russian project, with its approximately 10 million forged U.S. dollars, arose out of the Soviet Union's economic plight at the time. The Hungarian undertaking, on the other hand, with its reported 1.5 billion bogus French francs, had been designed to embarrass the French government politically, damage it economically, yield funds for irredentist propaganda and intelligence activities, and serve on the whole as partial revenge for blows dealt by the post-World War I Treaty of Trianon (1920), which had truncated Hungary and for which, in Magyar eyes, France had been mainly responsible.

In the immediate postwar period the regime of Admiral Miklós Horthy, strongly influenced by chauvinist military leaders, was driven by a twopronged urge for revenge in connection with the lost war and its early aftermath. Domestically this found expression in what came to be called the White Terror, a nationwide drive by vigilante formations against suspected supporters of the 1919 Red Terror regime of Communist dictator Béla Kun. The excesses of this campaign led to investigations by international commissions and protests in Western parliaments. Abroad, the designated target of vendetta was France, where Clemenceau, "the Tiger," and his successors symbolized for Hungarian revanchists just about everything to which the nation's plight could be rightly or wrongly ascribed. It was in this connection that a conspiracy for international political sabotage was devised with the

1. Arnold Krammer, "Russian Counterfeit Dollars: A Case of Early Soviet Espionage," Slavic Review, 30, no. 4 (December 1971): 762-73. 
connivance or participation of former and active high officials who viewed their parts as matters of patriotic duty.

The opening event, on December 21, 1925, was much like a scene in a hackneyed motion picture. An elegant, monocled gentleman of soldierly bearing appeared at the teller's window in a private bank at The Hague. Handing over a large French banknote, he requested change. Because the regular teller had just stepped out to respond to a call from the rear office, the client was served by the manager, who happened to be the city's leading expert in counterfeit notes and a consultant to the police in that field. According to his subsequent testimony, the thousand-franc bill "looked absolutely perfect" to him, but "somehow it did not give the right response to the fingers." After furnishing the desired change, he alerted the bank detective, who followed the gentleman to one of the city's elegant hotels and then notified both the bank and the police.

When two "valuta detectives" and the bank manager entered his suite and began to question him, the suspect, though startled and increasingly nervous, declared with no little dignity and indignation that he was beyond any possible suspicion and, in fact, immune to questioning or charges. He produced a diplomatic passport which identified him as Arisztid de Jankovich, "special courier for the Royal Hungarian Ministry of Foreign Affairs." While this exchange was in progress, one of the detectives noticed under the bed something lying near enough to be visible: another thousand-franc note. The expert scrutinized it at length and pronounced it false. One of the detectives, ignoring Jankovich's shrill protestations, looked into a steamer trunk which, closed but not locked, stood in a corner. It was filled with packets of thousand-franc notes, with many loose singles carelessly spread over them or pressed into gaps. Now almost hysterical, Jankovich demanded to see the Hungarian ambassador. Taken to the nearby Embassy, he was first received by the consul. In a sudden fit of rage, bellowing that he must see the ambassador himself at once, he blurted out, and repeated in French for the benefit of the Dutchmen, that he had been "assigned by the chief of the Hungarian national police to engage in special activities." The Dutch officials departed and proceeded immediately to the Foreign Office, which then took charge of the matter.

On the morning of December 22 the Foreign Ministry in Budapest received from the Embassy at The Hague a telegram which seemed to reflect some doubt about Jankovich's credibility: it bore a low security classification, comparable to our own Limited Official Use of today. It read: "Arisztid Jankovich in possession special courier certificate 14532 arrested by local police for attempt to pass counterfeit French francs and possessing same in large quantities. Claims authorization from Chief Captain of National Police 
Imre Nádosy for 'special activities,' also that Minister Nuber aware of his mission. Request confirmation of bona fides. (Signed:) Forster." The reply, received later that day, was highly classified: "Secret/Urgent, Eyes Only." It said: "Bona fides valid, special assignment confirmed. (Signed:) Nuber."

During the intervening hours, two additional Hungarians were arrested at The Hague as a result of warnings the police had issued to all foreignexchange bureaus in the Netherlands. Both men had passed false thousandfranc notes. Jankovich was a colonel of the Hungarian army's General Staff; these two were captains of that Staff, one of them György de Marsovszky and the other György de Mankovich, a nephew of former Minister of the Interior Baron Zsigmond Perenyi, head of the irredentist organization Nemzeti Szövetség (National Federation). The case broke in both the Dutch and the French press, and the Hungarian papers of the parliamentary opposition reprinted the essence of the reportage. Within a week the nation's highest-ranking police official, Nádosy, admitted to the ministers of justice and interior that he had personally issued special documentation for the arrested "couriers." Next it became known that a former minister of supplies, Prince Lajos Windischgraetz, was also implicated. Uproarious scenes followed in Parliament; the Horthy regime was faced with the most severe political crisis since its inception.

As a conspiratorial labyrinth opened up at cabinet meetings, parliamentary sessions, pretrial hearings, and finally criminal trials, it soon developed that the idea for the picaresque project had come from a foreign source. The earliest ascertainable contacts between Hungarian and German rightists were placed on the historical record, foreshadowing the regime's eventual move into the Nazi orbit, which ultimately led to Hungary's triple disaster: occupation by Hitler, war by the Allies, and "liberation" by Stalin.

Field Marshal Erich von Ludendorff, a friend of Horthy's in the days when the latter was in charge of the Austro-Hungarian fleet, had secretly written the regent at the very outset of his rule in 1920 . The marshal did so in his capacity as leader of the Bund Oberland (Highland Federation), a Bavarian extreme rightist organization of war veterans. He said: "Internal and external constellations alike make necessary the closest possible collaboration between us. ... I am, of course, quite aware of the need for caution, and I am especially mindful of the suspicions of the French; in fact, this is why I consider it best to postpone my trip to Hungary."

2. "A 25-ös Bizottság Jelentései" [Reports of the Parliamentary Committee of 25], Hungarian National Archives, Budapest, vol. 4, 1926.

3. Kozma Iratok [Kozma Documents], 1. csomó, adatgyújtemény, 1920-22, p. 12, Hungarian National Archives, Budapest. 
Two years before the explosion of the Frank $\ddot{u} g y$ (Franc Affair-the official Hungarian euphemism for the case), Ludendorff had come to the support of a rising agitator by participating in the man's attempt to seize power in Bavaria. In the full uniform of a field marshal of the defunct German imperial army, he marched across Munich's Feldherrnhalle at the side of Adolf Hitler, followed by Hess, Göring, Röhm, and other would-be leaders at the head of an armed group of heil-ing partisans. As a result of the unsuccessful Beer Hall Putsch, Hitler went to prison, but the state did not dare lay a hand on the grand old hero of the Vaterland.

Ludendorff went on to hatch schemes of his own, and it was during this period that the wealthy Austro-Hungarian peer, Prince Windischgraetz, on a visit to one of his estates in Germany, called on him. During their long discussions about possible clandestine operations whereby some of the stringent provisions of the peace treaties could be contravened, Ludendorff mentioned an unusual plan. He said that an organization supported by some prominent German industrialists in the French-occupied Ruhr region had planned to counterfeit French francs in huge quantities, and technical preparations had been virtually completed at the time of the Stresemann-Briand talks on Franco-German reconciliation. The agreement reached at Locarno rendered action at least temporarily impracticable, according to the planners, and Ludendorff wondered if perchance the Hungarians might not adopt the plan and take over the entire technical equipment. On his return to Budapest, the prince initiated secret discussions with a number of leading personages. Some have remained unidentified to this day. Soon a leading technician of the National Cartographic Institute, Major László Gerő, was recruited; he gained the cooperation of his chief, General Lajos Haits, who in turn persuaded the director of the Institute, General Sándor Kurtz, to join in the "patriotic" plot. An initial quantity of 9,000 pounds of specially treated paper was shipped from Cologne to Budapest under the supervision of the prince's secretary, Dezső Rába. Sealed railroad freight cars brought the machinery from Bavaria to Budapest. The first batch of counterfeit bills, 30,000 thousand-franc notes, was ready in September 1925. It was secretly transported to storage rooms in the huge residence of Bishop István Zadravetz, chief chaplain of the Hungarian army.

The director general of the State Postal Savings Institute, former Minister of Finance Gábor Baross, accepted the role of consultant on matters concerning "circulation," that is, distribution of the bogus bills abroad. Twelve "special couriers" were assigned to cover initially the Netherlands, Sweden, Italy, and Belgium, in that order. Each an active or reserve officer of the army's General Staff, they had instructions to have the bills changed at private banks and, after the completion of the entire action, transfer the heaps 
of genuine bills to the Institute through the diplomatic pouches of Hungarian embassies. Only at that final stage were the ambassadors to be informed about the nature of the project. Bishop Zadravetz took from each special "courier" an oath of religious and "patriotic" solemnity concerning the secrecy of the assignments, and ceremonially blessed them before departure.

While one sensational arrest followed another, the French government retained an experienced and courageous Hungarian lawyer, Dr. Paul de Auer, to represent it. The trials were attended by some of the most famous newspaper correspondents of the time, including American star reporters Dorothy Thompson and H. R. Knickerbocker.

Prince Windischgraetz admitted in court that he and "various friends and comrades" had planned and implemented "certain endeavors which called for unusual steps in the service of patriotic objectives." However, he declared: "In the national interest, I refuse to reveal who played what role, and where the banknotes had been produced." $4 \mathrm{He}$ admitted also that some of the expected huge proceeds were to be spent in three ways: to "influence" elections in Slovakia (in formerly Hungarian areas) by financing some activities of the Slovak autonomous movement, to lay the groundwork for as yet undetermined domestic political projects, and to support "sympathetic causes abroad."

It was revealed during the trials that in the fall of 1925 the prime minister, Count István Bethlen, had received at least one intelligence report about the counterfeiting operation from Deputy Foreign Minister Count Sándor Khuen-Héderváry. Bethlen had passed it on to the head of the national police-conspirator Nádosy. In one of many dramatic hours at the trials, testimony was taken from the prime minister; his candor seemed to have its rather distinct limits. Under increasing attacks in Parliament and the press, he withdrew to his Trans-Danubian estate shortly after first-level sentences had been passed on the conspirators in June 1926, and directed his cabinet from afar.

At the first trial Auer declared: "When I, a Hungarian lawyer, request justice from a Hungarian court for the French Republic, I also request the French Republic for understanding in this tragic Hungarian case."5

Prince Windischgraetz and Chief Captain Nádosy were each given four years in prison and heavily fined; Generals Kurtz and Haits received one year each, Major Gerő two years, and Rába one and a half years. The court found "extenuating circumstances" in each case on grounds of the "fact that

4. Nemzetgyülesi Napló [Parliamentary Record], vol. 2, 1927.

5. Paul de Auer, Fél évszazad [Half Century] (Washington, D.C.: Occidental Press, 1971), p. 134. 
the defendants were not criminals at heart and acted under patriotic impulses." On appeal, about three months later, the sentences of the prince and the police commandant were confirmed; those of Gerô and Rába were reduced by six months. Before this, Rába had withdrawn some parts of his previous testimony which tended to incriminate Bethlen, several politicians close to him, and some Germans. One of the little-known collaborators of the plotters, Reserve Captain György Hir, who had also implicated some of these people, refused to revise or withdraw his earlier statements. This, as it happened, entailed no further complications, because two weeks before the Curia (Supreme Court) pronounced the last word in the case, Hir died.

None of the courts dealt with any complicity on the part of Bethlen or any member of his cabinet. Under the pressure of public opinion at home and abroad, Bethlen addressed a letter to the regent in which he said in part: "... . it is fitting that the government ... draw the political consequences and submit its resignation. I have not taken this step earlier partly because up to now the resignation would have been regarded-both at home and abroad-as though the government was a party in counterfeiting francs, and partly because I considered it politically dangerous to make it in effect possible for the French and Czech governments to put the Hungarian government out of business. This would have created the most dangerous precedent. These considerations do not apply any more today. . . . Nevertheless, the resignation may still prove useful from the angle of foreign policy."

The regent refused to accept Count Bethlen's resignation; the prime minister, to placate the public, "reconstituted" his cabinet to the extent of replacing Minister of the Interior Rakovszky, whose portfolio governed the national police force. The Curia confirmed the prince's sentence, reducing all others by several months. But neither of the two convicted principals remained in prison for long. After a few weeks behind bars Windischgraetz moved to the elegant Park Sanatorium, where he proceeded to receive guests and throw lavish parties. Before long he began to appear at night clubs, and even made trips to the Italian Riviera, while "technically" in prison. On March 1, 1927, Regent Horthy granted clemency to Nádosy, and on May 26 to the prince. The most outlandish plotter, Bishop Zadravetz, was penalized by the highest church authorities: he had to resign as chief military chaplain and withdraw for two years to an Austrian monastery. Upon his return he was granted an army general's pension, retroactive to his resignation. Reverberations of the case persisted for several years. Even four years after the

6. Bethlen to Horthy, Sept. 24, 1926, doc. 13, in Miklós Szinai and László Szúcs, eds., Horthy Miklós titkos iratai [Miklós Horthy's Secret Papers], 2nd ed. (Budapest, 1963), pp. 62, 66. This letter appears as doc. 11 in an English version of the book: The Confidential Papers of Admiral Horthy (Budapest, 1965). 
final verdict, the Hungarian Council of Honor of General Officers found it necessary to try to salvage as much of the prince's reputation as seemed possible. The self-styled court of top-ranking officers certified in a "verdict" of its own: "Prince Lajos Windischgraetz, quondam Imperial and Royal Secret Councillor, Cabinet Minister, Ambassador and Major, has not violated the officer's code of honor-neither in regard to himself nor with respect to anyone else ...., having proceeded on the basis of instructions from higher quarters [sic]. He has furnished an example of unselfish patriotism worthy of our best traditions."

A young man, one of the most assiduous attendants at the open sessions of the trials and within a few years himself a General Staff officer, also had certain ideas of his own about the national interest. He wrote denunciatory letters to editors whose newspapers attacked the "patriots" of the Frank ügy. His name was Ferenc Szálasi. In 1944 he replaced Horthy through a putsch made possible by Ludendorff's erstwhile associate-Hitler.

7. Louis Windisch-Graetz, Helden und Hahunken [Heroes and Scoundrels] (Vienna, 1965), p. 127. 